\title{
Insecticidal Properties of some Plant Extracts against Granary Weevil, Sitophilus granarius $\mathbf{L}$.
}

\author{
Rania E. El-Araby ${ }^{1}$; Aly A. El-Sebae ${ }^{1}$ and Awad A. Farahat ${ }^{2}$ \\ ${ }^{1}$ Environment Protection Dept., Faculty of Environmental Agricultural Sciences, Suez Canal University. \\ ${ }^{2}$ Plant Protection Dept., Faculty of Agricultural Sciences, Suez Canal University.
}

\section{Received: $9 / 10 / 2013$}

\begin{abstract}
Laboratory experiment was conducted under controlled conditions to test the insecticidal activity of aqueous and organic extract of different solvents (ethanol, acetone and hexane) of three plants collected from northSinai (Tree tobacco, Nicotiana glauca G.; Chinaberry, Melia azedarach L. and Lemon, Citrus limon L.) against the adult stage of Granary Weevil, Sitophilus granarius L. The results showed that the aqueous extract of $C$. limon gave the highest toxicity among the other tested plants with LD50 equal to $0.0013 \times 10^{5} \mathrm{ppm}$ using ethanol solvent. However, the organic extracts of $M$. azedarach L. showed the best result with LD50 equal to $0.00056 \times 10^{5} \mathrm{ppm}$. On the other hand, both the aqueous and organic extracts of $N$. glauca gave the highest toxicity with LD50's of $0.0056 \times 10^{5} \mathrm{ppm}$ and $0.00086 \times 10^{5} \mathrm{ppm}$, respectively, with acetone solvent. But by using hexane solvent, aqueous extract of $N$. glauca was obviously the most superior in toxicity compared to the aqueous extracts of the tested plants with LD50 $\left(0.0017 \times 10^{5}\right.$ $\mathrm{ppm}$ ) and in the organic phase $M$. azedarach had the best result with LD50 equal to $0.00017 \times 10^{5} \mathrm{ppm}$.
\end{abstract}

Keywords: Insecticidal activity, Nicotiana glauca, Melia azedarach, Citrus limon, Granary Weevil.

\section{INTRODUCTION}

Insect infestation of stored grains and there products is a serious problem throughout the world. Annual worldwide post-harvest losses due to insect damage, microbial deterioration and other factors are estimated to be $10-25 \%$ (Matthews, 1993). Chemical insecticides are currently the method of choice to protect stored grains from insect damage (Domeracki and Zpierska, 1982; Karas et al., 2001; Bell et al., 2003 and Drinkall et al., 2005); however, their widespread use has led to the development of pest strains resistant to insecticides (Subramanyam and Hagstrum, 1995). As a result, there is a demand for safer insecticides because of concern about insecticide residues on grain and health hazards to grain handlers. Hence, an alternative to synthetic insecticides especially methyl bromide which depletes the stratospheric ozone layer is of utmost importance (Drinkall et al., 2005).

Many natural products are used exclusively as stored-product protectants. Such products have been used to control stored-product insect pests since the dawn of agriculture (Levinson and Levinson, 1998). In addition to being toxic, many natural products are also repellent or attractant to stored-product insects. Growing public concern for the environment has contributed to the change in attitude towards the use of botanicals in pest control. The use of natural products of plant origin is a new trend that preserves the environment from pollution with harmful toxicants. Several studies have suggested the use of plant extracts
(Yadova, 1971; Su et al., 1972; Schoonhoven, 1978; Singh et al., 1978; Nassar et al., 1995; Azadbakht et al., 2004 and Negahban et al., 2007).

On the basis of the above information, the present work was conducted to evaluate the efficiency of aqueous and organic extracts of some wild plants against the adult stage of the Granary weevil, Sitophilus granarius L.

\section{MATERIALS AND METHODS}

\section{Rearing methods of the tested insects:}

Laboratory culture of adult stage of Granary weevil, Sitophilus granarius L. was used in the present study for bioassay test, wheat grains were used as rearing media for the tested insect. The insect breeding was carried out in special containers of $15 \mathrm{~cm}$ diameter and $30 \mathrm{~cm}$ height and was kept under laboratory conditions within $27 \pm 3^{\circ} \mathrm{C}$ and $65 \pm 5$ R.H.

\section{Collection and identification of tested plants:}

The following plant samples were collected from the area surrounding Arish Airport (Table 1). Identification of tested plants was based mainly on the taxonomic characters detailed by Boulos and El-Hadidi (1984), and revised through personal communication with Dr. Hameda Bedair (Faculty of Education, Suez Canal University). Plant samples (Table 1) were air dried for 2-4 weeks until complete dryness, and then milled in an electric grinder into a fine powder and stored until used.

Table (1): List of the tested plant species and their extract parts.

\begin{tabular}{cccc}
\hline No. & Tested plants & English name & Extract part \\
\hline $\mathbf{1}$ & Melia azedarach $\mathrm{L}$. & Chinaberry & Seeds \\
$\mathbf{2}$ & Citrus limon $\mathrm{L}$. & Lemon & Leaves \\
$\mathbf{3}$ & Nicotiana glauca $\mathrm{G}$. & Tree Tobacco & Leaves and flowers \\
\hline
\end{tabular}

\section{Organic and aqueous extraction:}

Twenty grams of each dried plant part (Table 1) was soaked in a dark flask containing $100 \mathrm{ml}$ of one from three solvents (Ethanol, Acetone and Hexane) for organic extraction of each sample. The mixture was allowed to stand for 24 hours, and then filtered using whatman No.1 filter paper on Büchnur funnel. The obtained filtrate liquid represents the organic extract for 
each sample. Simultaneously, the solid deposit on the Büchnur funnel was washed with $100 \mathrm{ml}$ of distilled water for each. The obtained water wash resembles the water extract for each plant sample. Both organic and water extracts were freshly prepared and used for the bioassay purposes.

\section{Bioassay tested for each of the organic and aqueous extracts:}

Series of dilutions with distilled water for water extracts, or with (Ethanol, Acetone and Hexane) solvent for the organic extracts were prepared for each stock solution. The dilutions were $1 / 10,1 / 100,1 / 1000$ and $1 / 10000$ of original stock solution. For the bioassay treatments, five Petri dishes each containing 20 adults of the tested insect and each insect was topically treated with $5 \mu \mathrm{l}$ with the micro applicator (McCloud et al., 1988; Pemonge et al., 1997; Zapata and Smagghe, 2010). Five replicates were used for each treatment, including the control. Average percentage mortality was recorded for each after $24 \mathrm{hrs}$. LD50 values and the corresponding slopes were deduced from the regression lines (Finney, 1952), and confidence limits were computed using the normal equivalent deviate program.

\section{RESULTS}

The insecticidal activities of the aqueous and organic extracts of the tested plants against Sitophilus granarius are summarized in table (2 and 3). The results indicated that the aqueous extract of Citrus limon showed the highest insecticidal activity with LD50 equal to $\left(0.0013 \times 10^{5} \mathrm{ppm}\right)$ when we used ethanol solvent. Melia azedarach was the second in toxicity (LD50 $\left.=0.0015 \times 10^{5} \mathrm{ppm}\right)$ followed by Nicotiana glauca with LD50 $\left(0.0032 \times 10^{5} \mathrm{ppm}\right)$ (Table 2). However, organic extract of Melia azedarach was the most superior in toxicity compared to the other organic extracts of the tested plants. LD50 value for Melia azedarach was $0.00056 \times 10^{5} \mathrm{ppm}$. Citrus limon was the second toxicity against adults of Sitophilus granarius $\left(\right.$ LD50 $\left.=0.0007 \times 10^{5} \mathrm{ppm}\right)$ followed by Nicotiana glauca with LD50 equal to $0.00078 \times 10^{5} \mathrm{ppm}$ (Table 3 ).

Result proved when we used Acetone solvent, both aqueous and organic extracts of Nicotiana glauca were the highest in toxicity than other extracts of tested plant species with LD50 equal to $\left(0.0056 \mathrm{x} 10^{5} \mathrm{ppm}\right)$ in aqueous extract and $\left(0.00086 \times 10^{5} \mathrm{ppm}\right)$ in the organic phase extract against the adult stage of Sitophilus granarius (Table 2-3). Aqueous extract of Melia azedarach was the second in toxicity among all tested extracts followed by Citrus limon with LD50 equal to $\left(0.17 \times 10^{5} \mathrm{ppm}\right)$ and $\left(0.019 \times 10^{5} \mathrm{ppm}\right)$ respectively (Table 2). However, Organic extract of Melia azedarach was the second in toxicity with LD50 equal to $(0.008 \mathrm{x}$ $\left.10^{5} \mathrm{ppm}\right)$. The lowest toxicity was found with Citrus limon in the organic extract of acetone solvent with LD50 equal to $\left(0.06 \times 10^{5} \mathrm{ppm}\right)$ (Table 3$)$.

Data in table (2) showed that the aqueous extract of Nicotiana glauca was the highest insecticidal activity with LD50 equal to $\left(0.0017 \times 10^{5} \mathrm{ppm}\right)$ when we used hexane solvent. Melia azedarach was the second in toxicity $\left(\mathrm{LD} 50=0.002 \times 10^{5} \mathrm{ppm}\right)$ and Citrus limon was the lowest in toxicity among all tested plant extracts with LD50 equal to $\left(0.0032 \times 10^{5} \mathrm{ppm}\right)$. However, organic extract of Melia azedarach was the highest in toxicity than other aqueous extracts of the tested plants with LD50 equal to $\left(0.00017 \times 10^{5} \mathrm{ppm}\right)$. Nicotiana glauca was the second in toxicity against Sitophilus granarius $\left(\right.$ LD50 $\left.=0.0005 \times 10^{5} \mathrm{ppm}\right)$ followed by Citrus limon with LD50 equal to $\left(0.0023 \times 10^{5} \mathrm{ppm}\right)$ (Table 3).

Table (2): LD50, slope and confidence limits value of aqueous extract of the tested plants against the adult stage of Sitophilus granarius

\begin{tabular}{|c|c|c|c|c|}
\hline The solvent & Plant & LD50 (ppm) & Slope & Confidence limits of LD50 \\
\hline \multirow{3}{*}{ Ethanol } & Melia azedarach $\mathrm{L}$. & $0.0015 \times 10^{5}$ & 0.5766 & $0.00048 \times 10^{5}-0.00468 \times 10^{5}$ \\
\hline & Citrus limon L. & $0.0013 \times 10^{5}$ & 0.5926 & $0.00032 \times 10^{5}-0.00535 \times 10^{5}$ \\
\hline & Nicotiana glauca $\mathrm{G}$. & $0.0032 \times 10^{5}$ & 0.4812 & $0.00089 \times 10^{5}-0.01156 \times 10^{5}$ \\
\hline \multirow{3}{*}{ Acetone } & Melia azedarach L. & $0.0170 \times 10^{5}$ & 0.3879 & $0.00576 \times 10^{5}-0.05017 \times 10^{5}$ \\
\hline & Citrus limon L. & $0.0190 \times 10^{5}$ & 0.3809 & $0.00508 \times 10^{5}-0.07107 \times 10^{5}$ \\
\hline & Nicotiana glauca $\mathrm{G}$. & $0.0056 \times 10^{5}$ & 0.4539 & $0.00174 \times 10^{5}-0.01798 \times 10^{5}$ \\
\hline \multirow{3}{*}{ Hexane } & Melia azedarach L. & $0.0020 \times 10^{5}$ & 0.5470 & $0.00055 \times 10^{5}-0.00724 \times 10^{5}$ \\
\hline & Citrus limon L. & $0.0032 \times 10^{5}$ & 0.5000 & $0.00094 \times 10^{5}-0.01094 \times 10^{5}$ \\
\hline & Nicotiana glauca $\mathrm{G}$. & $0.0017 \times 10^{5}$ & 0.5614 & $0.00055 \times 10^{5}-0.00527 \times 10^{5}$ \\
\hline
\end{tabular}

Table (3): LD50, slope and confidence limits value of organic extract of the tested plants against the adult stage of Sitophilus granarius

\begin{tabular}{|c|c|c|c|c|}
\hline The solvent & Plant & LD50 (ppm) & Slope & Confidence limits of LD50 \\
\hline \multirow{3}{*}{ Ethanol } & Melia azedarach $\mathrm{L}$. & $0.00056 \times 10^{5}$ & 0.7273 & $0.00014 \times 10^{5}-0.00232 \times 10^{5}$ \\
\hline & Citrus limon L. & $0.00070 \times 10^{5}$ & 0.6809 & $0.00024 \times 10^{5}-0.00204 \times 10^{5}$ \\
\hline & Nicotiana glauca $\mathrm{G}$. & $0.00078 \times 10^{5}$ & 0.6667 & $0.00031 \times 10^{5}-0.00199 \times 10^{5}$ \\
\hline \multirow{3}{*}{ Acetone } & Melia azedarach L. & $0.00800 \times 10^{5}$ & 0.4324 & $0.00284 \times 10^{5}-0.02253 \times 10^{5}$ \\
\hline & Citrus limon L. & $0.06000 \times 10^{5}$ & 0.3316 & $0.01750 \times 10^{5}-0.20570 \times 10^{5}$ \\
\hline & Nicotiana glauca $\mathrm{G}$. & $0.00086 \times 10^{5}$ & 0.6465 & $0.00020 \times 10^{5}-0.00367 \times 10^{5}$ \\
\hline \multirow{3}{*}{ Hexane } & Melia azedarach L. & $0.00017 \times 10^{5}$ & 0.6809 & $0.00004 \times 10^{5}-0.00082 \times 10^{5}$ \\
\hline & Citrus limon L. & $0.00230 \times 10^{5}$ & 0.5333 & $0.00068 \times 10^{5}-0.00776 \times 10^{5}$ \\
\hline & Nicotiana glauca $\mathrm{G}$. & $0.00050 \times 10^{5}$ & 0.7356 & $0.00019 \times 10^{5}-0.00132 \times 10^{5}$ \\
\hline
\end{tabular}




\section{DISCUSSION}

Bioassays with aqueous extract of fruit and leaves of the Chinaberry tree, Melia azedarach against adults of Bemisia tabaci showed significant repellent activity and decreased the oviposition rate of the insect (Hammad et al., 2001).

In another study, Chinaberry tree, Melia azedarach has a potent mosquito larvicidal activity, and can be used for the control of mosquito, Anopheles stephensi populations (Pandey and Verma, 2002). Also, Su (1991) reported that the topical application of chenopodium (Chenopodium ambrosioides L.) oil to wheat seeds at $2000 \mathrm{ppm}$ reduced the infestation of Sitophilus oryzae L. While, Bodnaryk et al. (1999) found that extracts of pea (Pisum sativum L.) resulted in adult mortality and reduced the reproduction rate of several stored-product insect pests at a concentration as low as $0.01 \%$. The mortality was happened because of active ingredients found in the tested extracts which have potential insecticidal activities against the tested insects.

Meanwhile and by throwing more light, Bell et al., (1990) reported that the presence of so-called secondary metabolite compounds, which have no known function in photosynthesis, growth or other aspects of plant physiology, give plant materials or their extracts their anti-insect activity. Secondary metabolite compounds include alkaloids, terpenoids, phenolics, flavonoids, chromenes and other minor chemicals can affect insects in several different ways, they may disrupt major metabolic pathways and cause rapid death, act as attractants, deterrents, phagostimulants, antifeedants or modify oviposition. They may retard or accelerate development or interfere with the life cycle of the insect in other ways. So that it can explain the high mortality by using such plants as potent insecticides (Lloyed, 1973; Huang et al., 1997; Asgary et al., 2000; Wink et al., 2004).

Also it can be mentioned that there are certain concentrations of aqueous or organic extracts of each plant, which could be named by the optimum and suitable concentrations which causing the best effect. Besides, the variations between each plant and its response and insect target sensitivity to the tested concentrations at each tested phase, i.e. the presence of polar and non polar compounds in the media of testing. So that it is offering a kind of physiological selectivity which occurred due to difference in type of mode of action showing a variability in type of toxic materials, its concentrations and its response. Also the role of genetic factor in elucidating difference in responses and reactions (Upitis et al., 1973; Arnaud et al., 2005)

In conclusion, and by focusing on the nature and body composition of the tested insect, Rynolds (1987) reported that the insect cuticle is a layered structure and the functions of the cuticle that are most vulnerable to insecticidal action are mechanical .These properties of the cuticle stiffness, strength, and hardness are largely due to the major part of the cuticle thickness. Cuticle is a composite material, made of proteins, lipids, phenolics and tannins. They confer chemical and mechanical stability to the cuticle by increasing the hydrophobicity of the cuticle matrix. And by more focusing on the nature and composition of the membranes and its effect by the used extracts on these membranes, Hamburger and Hostellman (1991) reported that the drug affects integrity of membranes and localized these membranes due to its highly lipophilic nature.

In the other side, chemical characteristics of the effective compounds such as charge and polarity of natural compound affecting rates of interchange especially across membranes and cuticles to determine whether it reaches that tissue or target at intoxicating concentrations (Gilpy, 1984).

\section{REFERENCES}

Arnaud, L.; Lan,H. T. T.; Brostaux, Y. and Haubruge, E. (2005): Efficacy of diatomaceous earth formulations admixed with grain against populations of Tribolium castaneum, Journal of Stored Products Research, Volume 41, Issue 2, pp (121-130).

Asgary, S.; Naderi, G. H.; Sarrafzadegan, N.; Mohammadifard, N.; Mostafavi, S. and Vakili, R. (2000). Antihypertensive and antihyperlipidemic effects of Achillea wilhelmsii. Drugs Exp. Clin. Res. 26, (89-93).

Azadbakht, M.; Golaipour, M. J.; Khori,V.; Azarhoush, R. and Nayebpour, M. (2004): Effect of Achillea santolina on mice spermatogenesis, DARUJournal of faculty of pharmacy, Tehran University of Medical sciences, 12 (1): 36-39.

Bell, A. E.; Fellows, L. E. and Simoonds, S. J. (1990): Natural products from plants for the control of insect pests. E. Hodgson \& R.J. Kuhr, eds. Safer insecticide development and use. Marcel Dekker, USA.

Bell, C. H.; Wontner, H. and Sauvidou, N. (2003): Some properties of sulphuryl fluoride in relation to its use as a fumigant in the cereals industry, Advances in stored product protection proceedings of the $8^{\text {th }}$ international working conference on stored product protection,UK,2226 July 2002, pp (910-915).

Bodnaryk, R. P.; Fields, P. G.; Xie, Y.; and Fulcher, K. A. (1999): Insecticidal Factors from Field Peas. U.S. Patent No. 5, pp (955-982).

Boulos, L. and El-Hadidi, M. N. (1984): The weed flora of Egypt. The American University in Cairo Press, p (178).

Domeracki, S. and Zpierska, J. (1982): Residues of bromine in imported cereals and feed, RocznikiNauk-Rolniczych-E-Ochrona-Roslin, Volume 12 Issue 1-2, pp (225-230).

Drinkall, M. J.; Pye,C. D.; Bell,C. H.; Braithwaite, M.; Clack,S .R.; Ive, J. and Kershaw, S. (2005): The Practical use of the fumigant sulfuryl fluoride to replace methyl bromide in UK flour mills, Using cereal science and technology for the benefit of consumers Proceeding of the $12^{\text {th }}$ International ICC Cereal and Bread Congess, Harrogate, UK, 23-26 ${ }^{\text {th }}$ May 2004, pp(245-249).

Finney, D. F. (1952): Probit Analysis. Cambridge University press, $\mathrm{p}$ (256). 
Gilby, A. R. (1984): Cuticle and insecticides. In Biology of the integument. Springer-varlog, Berlin, pp (644-702).

Hamburger, M. and Hostellman, K. (1991): Bioactivity in plants: The link beteeen phytochemistry and medicine. Phytochemistry Volume 30, Issue 12, pp (3864-3874).

Hammad, E. M.; Zournajian, H.; and Talhouk, S. (2001): Efficacy of extracts of Melia azedarach L. callus, leaves and fruits against adults of the sweet potato whitefly Bemisia tabaci H.. Journal of Applied Entomology, Volume 125, No.8, pp (483-488).

Huang, Y.; Tan, J. M. W. L.; Kini, R. M. and Ho, S. H. (1997): Toxic and antifeedant action of nutmeg oil against Tribolium castaneum H. and Sitophilus zeamais M., Journal of Stored Products Research, Volume 33, Issue 4, pp (289298).

Karas, S. A.; Slepchenko, V. L. and Iskulov, F. F. (2001): Fumigation of containers, Zashchita Karantain - Rastenii, (5), pp (26-32).

Levinson, H. and Levinson, A. (1998): Control of stored food pests in the ancient Orient and classical antiquity. Journal of Applied Entomology. Vol. (122), pp (137-144).

Lloyd, C. J. (1973) : The toxicity of pyrethrins and five synthetic pyrethroids, to Tribolium castaneum H., and susceptible and pyrethrin-resistant Sitophilus granarius L., Journal of Stored Products Research, Volume 9, Issue 2, pp (77-92).

Matthews, G. A. (1993): Insecticide application in stores. In: Matthews, G.A. and Hislep, E.C. [Eds.] Application Technology for Crop Protection. CAB, London, UK. pp (305-315).

McCloud, T. E.; Nemec, J.; Muschik, G.; Sheffield, H. G.; Quesenberry, P.; Suffness, M.; Gragg, G.; and Thampson, J. (1988): Extraction of bioactive molecules from plants, International Products Research, Park City, Utah, pp (17-21).

Nassar, O. A.; Ibrahim, S. M. and Iskander, A. K. F. (1995): Biological and Toxicological studies of certain plant extracts on Euteranychus anneckei Meyer and Tetranychus urticae koch, Egyption journal of agricultural research.

Negahban, M. ; Moharramipour, S. and Sefidkon, F. (2007): Fumigant toxicity of essential oil from Artemisia sieberi Besser against three storedproduct insects, Journal of Stored Products Research, Volume 43, Issue 2, pp (123-128).

Pandey, H. P. and Verma, B. K. (2002): Biotoxicity screening of Melia azedarach L. against mosquito (Anopheles stephensi Liston.), Journal of Phytological Research, Volume 15, Issue 2, pp (221-223).
Pemonge, J.; Villalobos, M. J. P. and Roger, C. R. (1997): Effects of material and extracts of Trigonella foenum-graecum L. against the stored product pests Tribolium castaneum $\mathrm{H}$. (Coleoptera: Tenebrionidae) and Acanthoscelides obtectus S. (Coleoptera: Bruchidae), Journal of Stored Products Research, Volume 33, Issue 3, pp (209-217).

Rynolds, S.E. (1987): The cuticle, growth and moulting in insects: The essential background to the action of Acylurea. Insecticides-pesticides sciences, Volume 20, pp (131-146).

Schoonhoven, A.V. (1978): Use of vegetable oils to protect stored beans from bruchid attack, J. Econ. Entomol. 74 (5): pp (254-256).

Singh, S.; Luse, R.; Leuschner, K. and Nangtu, D. (1978): Groundnut oil treatment for the control of C. maculatus, J. stored prod. Res., (14): pp (7780).

$\mathrm{Su}$, H. C. F. (1991): Toxicity and repellency of chenopodium oil to four species of storedproduct insects. J. Entomol. Sci. Volume 26, pp (178-182).

Su, H. C. F.; Speirs, R. D. and Mahrany, P. D. (1972): Citrus oil as Protectants of black eyed peas against Cow pea beetle, Journal of Econ. Entomol. Volume 65, Issue 1, pp (1433-1436).

Subramanyam, B. and Hagstrum, D. (1995): Resistance measurement and management. In: Subramanyam, B. and Hagstrum, D. [Eds.] Integrated Management of Insects in Stored Products. Marcel Dekker Inc.,New York, NY. pp. (331-398).

Upitis, E.; Monro, H. A. U. and Bond, E. J. (1973): Some aspects of inheritance of tolerance to methyl bromide by Sitophilus granarius L., Journal of Stored Products Research, Volume 9, Issue 1, pp (13-17).

Wink, M.; El-Shazly, A. M.; and Hafez, S. S. (2004): Comparative study of the essential oils and extracts of Achillea fragrantissima F. Sch. Bip. and Achillea santolina L. (Asteraceae) from Egypt. NCBI Journal, Vol. (59), No. 3, pp (226230).

Yadova, R. L. (1971): Use of essential oils of Acorous calanus L. as an insecticide against the pulse beetle Bruchus chinensis L., Z.angew.Ent., Volume 68, pp (289-294).

Zapata, N. and Smagghe,G. (2010): Repellency and toxicity of essential oils from the leaves and bark of Laurelia sempervirens and Drimys winteri against Tribolium castaneum, Industrial Crops and Products, Volume 32, Issue 3, pp (405-410). 


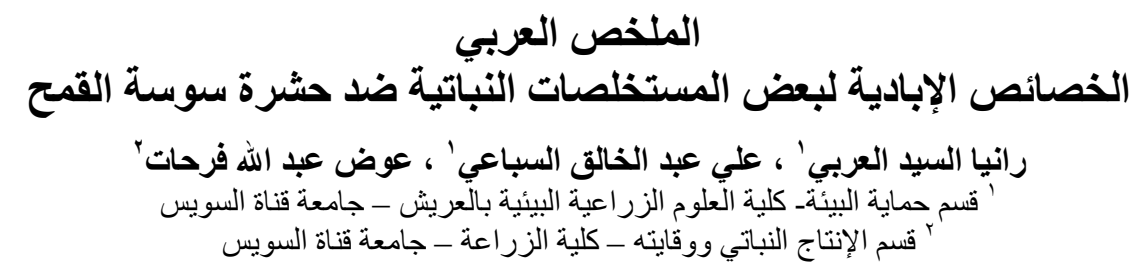

تم اختبار فاعلية وسمية كل من المستخلصات المائية والعضوية باستخدام ثلاثة مذيبات (ايثانولـ اسيتون_هكسـان) وذلك لثناثلاث نباتـات جمعت من صحر اء العريش و هي: نبات مصاص الدخان وأشجار الثنار الزنزلخت و أشجار الليمون وذللك ضد طور الحشرة الكاملة لسوسة القمح وقد

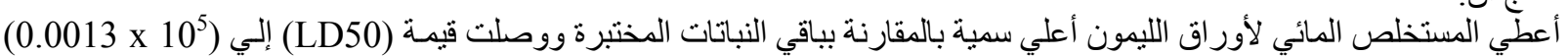

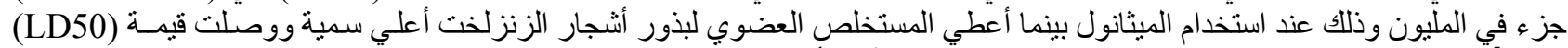

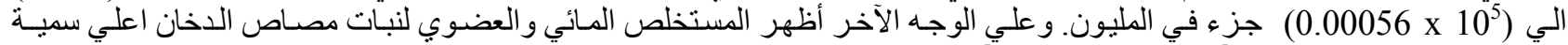

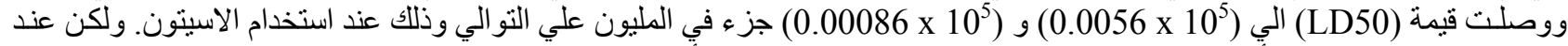

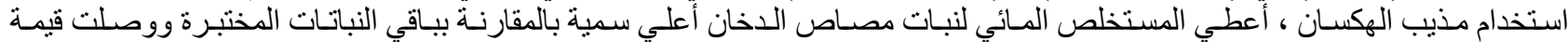

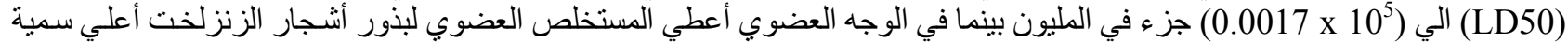

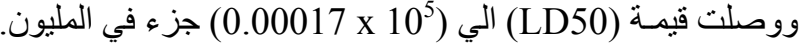

